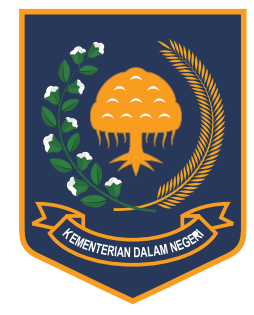

Jurnal Bina Praja 9 (1) (2017): 29-40

Jurnal Bina Praja

e-ISSN: 2503-3360 | p-ISSN: 2085-4323

Accreditation Number

735/AU2/P2MI-LIPI/04/2016

http://jurnal.kemendagri.go.id/index.php/jbp/index

\title{
THE LINKAgE OF INTERgOVERNMENTAL TRANSFER AND POVERTY IN INDONESIA
}

\author{
Heru Syah Putra * \\ Center for the Study and Education and Government Official Training IV \\ National Institute of Public Administration \\ Jl. DR. Mr. Teuku Haji Muhammad Hasan Kecamatan Darul Imarah Aceh Besar
}

Received: 5 December 2016; Accepted: 26 March 2017; Published online: 31 May 2017

DOI: $10.21787 /$ jbp.09.2017.29-40

\begin{abstract}
Decentralization is expected to reduce poverty. Through fiscal decentralization, poverty may be reduced by optimizing intergovernmental grants. However, its effect on poverty is beginning to be questioned after some districts in Indonesia showed slowing performance on poverty reduction despite increasing transfer. Thus, this paper tends to investigate the linkage of intergovernmental transfer (IT) and poverty in Indonesia. By using panel data from 2005 to 2013 , the linkage is tested using linear regression model. The result shows that increasing $1 \%$ of IT allocation will reduce poverty absolute by $0.12 \%$, or $10 \%$ increase of IT will reduce poverty by $1.24 \%$. The intergovernmental transfer also directly affects poverty gap and poverty rate. Increasing $10 \%$ of IT will reduce the poverty gap and poverty rate by 9.49\% and 31.73\%, respectively. Moreover, DAU (unconditional intergovernmental transfer) has a higher effect than DAK (conditional intergovernmental transfer) on poverty eradication. An increase of DAU by $1 \%$ will reduce the poverty number by $0.068 \%$, in contrast, DAK only has $0.0418 \%$ to reduce poverty. However, as the difference is relatively small, the effectiveness of DAU on poverty is not consistent with the decentralization theory. Unconditional grant must have a significant difference than conditional grant on poverty. It may indicate that the DAU has been spent ineffectively and inefficiently. It may also indicate that it has been spent on not pro-poor policies. Thus, fiscal decentralization in Indonesia needs to be reevaluated in order to support poverty alleviation program.
\end{abstract}

Keywords: Decentralization, Poverty, Intergovernmental Transfer

\section{INTRODUCTION}

The link between decentralization and service delivery is easily found. Its impact on those has been intensively studied by scholars (Cavalieri \& Ferrante, 2016; Hankla, 2009; Pal \& Wahhaj, 2015). However, the relationship between decentralization and poverty is less explored. This is mostly based on assumption that poverty is not the main reason of decentralization in many countries (Ali Khan, 2013). Most of the demand for decentralization relied on political power and natural resources. People and local governments asking for an equal development, especially infrastructure, is not directly for poverty reduction.

The impact of decentralization on poverty is gradually unveiled after it transformed into several types. Fiscal decentralization, one of the three types of decentralization, seems to have a closer effect on poverty reduction. By transferring budget allocation to local government, both conditional and unconditional transfer, it allows local government to create more pro-poor policies. A local government then is able to increase service delivery as it has more power and knowledge to local demand (Lewis, 2016). However, to have a positive effect on poverty reduction, a local government must have a strong incentive on allocating the grants to poverty-related programs (Bjornestad, 2009).

Despite having a positive effect on poverty, the intergovernmental transfer may lead to some negative effects. The transfer may discourage local government on funding its own spending and relying totally on central government transfer. It may also cause local government to overspend on specific posts that have no direct effect on poverty reduction.

\footnotetext{
* Corresponding Author

Phone : +628526070 0727

Email : heruaddaif@gmail.com
} 
Moreover, in some cases, fiscal decentralization increases the local's desire to generate other local government for more effective public good delivery reason (Mansoob Murshed, Zulfan Tadjoeddin, \& Chowdhury, 2009). These incentives may reduce the effectiveness of decentralization on poverty alleviation.

Indonesia has become a decentralized country since 1999 after the falling of New Order era. The benefit of decentralization was unveiled as poverty gradually dropped every year. In 2002, Indonesia achieved the most successful story on poverty reduction by cutting poverty about $20 \%$ (World Bank, 2016) . Transferred power from central to local governments was believed as an important factor that had a significant contribution to this achievement. Decentralization allowed local governments to spend the budget on more pro-poor spending. Further, decentralization also reduced relative poverty by increasing the quality of access to public goods and services.

However, the speed of poverty reduction in Indonesia has been slowing since the last decade. In 2013 and 2014 , it only reduced by $0.13 \%$ and $0.12 \%$, respectively. It contradicted to condition before 2004 that had average poverty reduction by $14 \%$. It also contradicted to the increasing decentralization by increasing authority to local government imposed by Laws. The first guidance of decentralization in Indonesia, Law Number 22 of 1999 and 24 of 1999, has been amended by Law Number 23 of 2004 about local government and Law Number 24 of 2004 about fiscal decentralization. These phenomena had triggered a question whether decentralization has a significant effect on poverty reduction or not.

Indonesian government adopts intergovernmental transfer (IT) by allocating intergovernmental transfer to local governments every year. Its purpose is to reduce the gap in fiscal capability among local governments. There are two types of IT in Indonesia, specifically intergovernmental transfer (DAK) and general intergovernmental transfer (DAU). On the other hand, DAU is allocated for equality purpose among local government. DAU is used for funding routine spending of local governments. Further, there is another type of IT namely revenue sharing fund (Dana Bagi Hasil (DBH)). However, this study does not consider it in the analysis.

A recent study discussing decentralization in Indonesia has mixed messages about the relationship between decentralization and poverty in Indonesia. Dana Dekonsentrasi (DD), another type of fiscal decentralization, has a positive impact on poverty alleviation. In contrast, Dana Tugas Pembantuan (DTP) shows a negative impact on poverty alleviation. Less controlled policies on DTP caused distortion on the budget allocation, both in local and central government (Lewis, 2016). Furthermore, another research that studied the effect of income growth on poverty rate after decentralization finds that if the average income per capita increases by $10 \%$, it would lead to a decrease in poverty rate almost 25\% (Miranti, Duncan, \& Cassells, 2014). However, there has not been a study yet concerning the direct effect of DAK and DAU on poverty in Indonesia.

Thus, this study tends to fill this need. The main purpose is to investigate the impact of the intergovernmental transfer on poverty in Indonesia. First, this study tends to test the correlation between intergovernmental transfer and poverty in Indonesia. Second, by comparing the effect of DAU and DAK on poverty, it tries to investigate which one is more effective on poverty reduction. It is expected that DAU has a higher effect on poverty reduction since it is an unconditional grant. This study starts with a brief overview of the linkages between decentralization and poverty. A review related to fiscal decentralization in Indonesia is explained next. To have a broad understanding, some previous studies are included in this section. At methodology section, there is a brief explanation of quantitative approach, as well as the data. In result and discussion section, the interpretation of the estimations is briefly explained and followed by comparison to previous studies.

\section{A. Fiscal Decentralization and Intergovernmental Grant}

The development of decentralization theory is started by a long debate about the right size and role of government in the economy. There are two approaches regarding this issue. The first approach suggests that government intervention must be limited and should be as small as possible in order to achieve efficiency in public service (Alam Siddiquee, 2006). This approach is based on the idea that by giving people the freedom to choose where they live, the government will be able to provide public goods at an efficient level; this is well-known as Tiebout Hypothesis. In contrast, the second approach suggests that government intervention must be enlarged and strengthen on any economic activity. It is based on three main functions of government; economic stabilization, income distribution, and resource allocation. The decentralization policy is based on the first approach.

Decentralization, its self, can be interpreted as a shift of authority and responsibility from central government to local government. In its application, the shift is not only occurred to local government but also many organizations such as regional authorities and private or voluntary nongovernmental organizations (Ali Khan, 2013). In some developed countries, provision of public 
goods has been transferred to private organizations. Furthermore, decentralization is basically divided into three types; de-concentration or administrative decentralization, devolution or democratic decentralization, and fiscal decentralization. Deconcentration or administrative decentralization means the shift of administrative responsibilities from central government to its government ministries and agencies. While devolution or democratic decentralization is the transfer of power and resources from the center to authorities at the lower levels, which are representatives of and accountable to the local population (Khan, 2016; Sudhipongpracha \& Wongpredee, 2016).

Decentralization commonly encounters the different capabilities among local government. Thus, it needs fiscal decentralization to reduce the gap (Mansoob Murshed et al., 2009). Fiscal decentralization is a transfer of fiscal revenue and fiscal sources from central government to local government. Its purpose is to reduce the gap of fiscal capacity among local governments. The main factor for fiscal transfer is net fiscal benefits (NFBs), the (Shah, 2007). NFB means the net benefit of public goods after considering the burden (tax). However, in reality, most of the local governments are not able to generate and collect sufficient revenue from their new delegated sources. It occurs because the transfer of power is not followed the transfer of capability of local government. Moreover, limited administrative capacity and local economic conditions may worsen the situation (Irawan, 2015; Khan, 2016; Loayza, Rigolini, \& Calvo-González, 2014). As consequence, it leads to an expanding gap.

Most central governments adopt revenue sharing, an approach for reducing the gap. This approach is well known as an intergovernmental transfer. The central government transfers some amount of grant to its local governments, those unable to fund their expenditures. There are two types of intergovernmental transfers, unconditional transfer and conditional transfer (Khan, 2016). Unconditional transfer gives full authority to local government to manage the fund freely without central government intervention. On the other hand, conditional transfer requires central government intervention, from planning to spending. Practically, the central government decides the type of activities funded by conditional transfer. Local government just follows its mechanism.

\section{B. The Benefits and the Risks of Fiscal Decentralisation}

The fiscal decentralization may produce not only positive effects but also negative effects. When the ideal conditions are not fulfilled, the negative effects may occur. Thus, the policy maker should be aware of both positive and negative effects of fiscal decentralization in order to mitigate further conditions. Based on experiences of many countries, World Bank (2016) has determined three positive effects of implementation of fiscal decentralization; improved efficiency, improved effectiveness, and improved political and financial accountability. Improved efficiency is linked to the condition of encouraging the competition for better use of public resources for public delivery. Fiscal decentralization promotes competition among subnational governments for limiting taxing power and maximizing their service delivery. As the people can choose where they live, especially rich people, local governments have to establish a friendlier environment to attract people to live in their districts. The local government that does not aware of this condition may lose the people, which leads to losing its potential taxpayer.

Improved effectiveness needs a close demand chain between government and people. The idea is as the local government has more information about the local need, then it is more appropriate to manage the public funds. The precise way of determining the number and type of public good only can be done by local government. In addition, in order to meet local needs, decentralization may also encourage innovation in public policy and service delivery, as individual jurisdictions have both the incentive and freedom to develop and implement new approaches or have incentives to copy successful sub-national governments. Furthermore, improved political and financial accountability is achieved by increasing the participation of citizens to control the implementation of fiscal decentralization. More power to local government means more control is needed to monitor the policies. Public participation is a fundamental requirement of decentralization, especially for the fiscal decentralization. The access of the funds must be widely accessible for the citizens and must be regularly reported to the people. By doing so, the accountability will be increased automatically.

The positive outcomes of fiscal decentralization only occur if ideal conditions are fulfilled. However, forgetting one condition or misconception of the mechanism lead to negative effects. The World Bank (2016) has determined four potential consequences of inappropriately designed fiscal decentralization in a country; declined investment in social infrastructures, increasing horizontal inequities and conflicts, the collapse of the safety net (poverty), and increasing corruption. Declining investment in social infrastructures may occur as local governments are accountable to their constituencies and compete among them to maximize spending while minimizing taxing. Thus, local governments, in deciding to undertake a particular activity or project, consider the cost of 
their decision. Therefore, they tend not to invest in social infrastructures (e.g. regional roads) which benefits go beyond their geographical boundaries.

Increasing horizontal inequities and conflicts may occur as local governments in a given country are different in terms of natural resources, the level of economic activities, population, and revenue capacity (Sudhipongpracha \& Wongpredee, 2016). Therefore, some local government will produce more revenue than others and provide to their citizen more or better quality services than is provided in poorer local governments. Moreover, the collapse of the safety net (poverty) is related to some local governments' inability to redistribute resources within their jurisdiction (Hull, 2001; Van \& Sudhipongpracha, 2015). Indeed, because of individual mobility, if sub-national governments attempt to redistribute from the rich to the poor, immigration of rich and immigration of poor may follow.

Increasing corruption cases may follow the misdesigned fiscal decentralization. Increased corruption is related to less developed and skilled local government than central government. The development of the centralized system has led the huge gap between local and central government on the ability and capability to manage the funds. Thus, decentralization absolutely encounters many types of problems regarding this gap. Corruption in local government may occur as the consequences of the misunderstanding of authority given to them. Furthermore, the political condition may lead the local authorities to follow the demand of political parties and tend to abuse the power and funds.

\section{Poverty}

Poverty has a broad meaning and dimension, not just associated with low income or consumption. Poverty can be grouped into three types; absolute poverty, relative deprivation, and capabilities deprivation (Khan, 2016). Absolute poverty, or wellknown as income-approach poverty, has a meaning that a condition of a person who is unable to satisfy a minimum level of income to fulfill his basic needs (Todaro \& Smith, 2009). Poverty determination refers to a minimum standard decided by a country or international institution. The minimum income for poverty is named the poverty line. World Bank has suggested a poverty line at the amount of US\$1 per day. After it, World Bank has changed the poverty line two times in 2005 and 2011, which were US\$1.25 and US\$1.9. However, many countries determine their own poverty lines, some use minimum consumption approach and others income approach. Indonesia is one of the countries that applies minimum consumption approach to determine poverty.

Relative poverty/deprivation means to a condition of an individual who is unable to maintain its living standard in a certain society. The appropriate living such as education, health, and social services are the aspects accounted when defining relative deprivation. Relative deprivation is related to happiness (Schalembier, 2016). Some people tend to compare their life to others in order to ensure they have a proper life in certain society. Furthermore, capabilities deprivation is assessed by a function of an individual or household in a society. An individual that has less or no function in a society is included in capability deprivation or poverty. This approach is developed by Sen (World Bank, 2005). The significant difference between relative deprivation and capabilities deprivation is in term of function. Although an individual is able to fulfill or achieve a minimum standard of living, he may still be categorized as capability deprivation.

Poverty may be related to regional, community, household, or individual characteristics. At the regional poverty, it is high in areas characterized by geographical isolation, a low resource base, low rainfall, and other inhospitable climatic conditions. Further, at the community level, infrastructure is a major determinant of poverty (World Bank, 2016) . Some infrastructures are often used in econometric exercises include the availability of electricity, availability of schools and medical clinics in the area, and distance to local administrative centers. Studies that focus on community-level characteristics also consider the average human resource development, access to employment, social mobility, and representation as the representative of community variables that affect poverty (Greenstein, Gentilini, \& Sumner, 2014; Malik, Mahmood-Ul-Hassan, \& Hussain, 2006; Yeoh, Ling, \& Shy, 2012). At household and individual characteristics, many studies include the age structure of household members, education, the gender of the household head, and the extent of participation in the labor force as variables that have a significant effect on poverty (Beard, 2007; Okurut \& Charles, 2014; Qibthiyyah \& Utomo, 2016). In poverty studies, the survey also includes the type of food, water resources, health condition, and assets possession as the variables (Biltonen \& Dalton, 2003; Hammer \& Spears, 2016).

\section{The Link between Fiscal \\ Decentralization and Poverty}

Decentralization is one of the important policies to eradicate poverty and deprivation, especially in developing country (World Bank, 2005). It promotes more pro-poor policies bringing policy maker closer to society. Decentralization also increases the efficiency on providing public service by reducing excess supply of public goods and services (Sudhipongpracha \& Wongpredee, 2016). Further, Decentralization is believed to be an effective tool 
for increasing income and access to basic services (Steiner, 2007). By giving the authority for local government to decide type and number of public goods, the provision might be close to the society demand. thus, optimization on the provision of the public good is achieved. Fiscal decentralization (FD) increases livelihoods for the poor (Bjornestad, 2009; Sudhipongpracha, 2016). Before FD is adopted, local governments only had few policies that could be executed regarding budget constraints, even it may be worse for some less-fortune local governments. Therefore, the increasing allocated funding by FD brought new hope for local government, especially fiscally disadvantaged localities, to provide more public goods and services. In return, it may reduce poverty, both absolute poverty, and relative poverty.

Ali Khan (2013) identifies three potential links between decentralization (devolution) and poverty by working out a conceptual framework. First, decentralization might lead to improvements in economic growth, which may, in turn, reduce absolute poverty. Second, regional targeting and economic efficiency may at the same time also accrue in improving the provision of public services, which may result in a decrease in the prevailing extent of relative deprivation. Third, he concludes that through increased participation and representation, decentralization might empower the impoverished and disadvantaged people in the decision-making process, which may lead to a reduction in deprivation of certain capabilities.

However, the benefit of fiscal decentralization differs among countries. By testing the effect of fiscal decentralization in Indonesia and Thailand, Sudhipongpracha (2016) finds that Indonesia's fiscal decentralization is more equitable and consistent with local poverty situations than Thailand's. The local governments in Indonesia with more impoverished population and less per capita income receive more general grants per capita than the affluent areas. On the contrary, richer jurisdictions in Thailand are given more per capita transfers than the more economically disadvantaged communities.

Bjornestad (2009) finds that fiscal decentralization in Vietnam contributes to poverty reduction outcomes. However, he argues that decentralization may promote efficiency. He finds that decentralization may increase more pro-poor policies with or without efficiency achievement. A recent study that answers the longdebated discussion is conducted by Lewis (2016). He estimates the different effect of two types decentralization policy, Dana Dekonsentrasi (DD) and Dana Tugas Pembantuan (DTP), on poverty rate in Indonesia. He finds that Dana Dekonsentrasi (DD), another type of fiscal decentralization, has a positive impact on poverty alleviation in Indonesia. In contrast, Dana Tugas Pembantuan (DTP) shows a negative impact on poverty alleviation. Less controlled policies on DTP caused distortion on the budget allocation, both in local and central government.

\section{E. Fiscal Decentralization in Indonesia: Institutional Background}

Indonesia adopted centralized administrative structures before 1997. As the demand for decentralizing after the financial crisis was increasing, Indonesia followed international demand by changing its system to become a decentralized country (Uchimura, 2012). However, Indonesia started full fiscal decentralization in the early 2000s, after the enactment of Law 22 and Law 25; and further revised by Law 32 and Law 33 in 2004. These laws have explicitly stated the division of responsibilities between central and sub-national governments (province level and district level) and outlined policies on how the central government will finance those devolved responsibilities to sub-national governments. The new laws state that fiscal decentralization consists of three principles: devolution, de-concentration, and coadministration. The concept being introduced by the new laws is devolution. Sub-national governments are able to exercise fiscal autonomy on a set of functions assigned to them. On the other hand, the central government creates fiscal transfers in order to co-finance those assigned functions-this is known as finance follows function. This policy of substantial devolution of roles and responsibilities to local governments has been the basis of the socalled 'Big Bang' decentralization in Indonesia.

The types of intergovernmental fiscal transfers, established under Law of the Republic of Indonesia Number 33 (2004), consist of General Allocation Grant (DAU), Specific Allocation Grant (DAK), and Revenue Sharing of some taxes and natural resources. DAU is a general-purpose grant issued from the central government budget (APBN) to all sub-national government budgets (APBD). It is also used as an equalizing grant to reduce horizontal imbalances. Allocation is based on a set of formulas. The basic formula consists of the following elements: a 'basic allocation'-which is the amount of local government employee's salary and the fiscal gap calculation (Minister of Finance of the Republic of Indonesia, 2012). The fiscal gap itself is calculated by subtracting expenditure needs from fiscal capacity. The calculation of fiscal need is based on the following components: population, surface area, cost price index, human development index, and the gross regional domestic products (GRDP) per capita index. Meanwhile, the fiscal capacity of local governments consists of their own source and shared revenues.

In the other hand, The DAK scheme is a 
specific purpose grant allocated from the APBN to certain sub-national governments and certain sector programs. The main purpose is to finance physical capital investment and to limit the period financing of operational and maintenance needs, in accordance with national priorities. Sub-national governments are also required to provide matching funds of at least $10 \%$ from the total DAK allocated in each sector. Further, the criteria for DAK are divided into general, special, and technical criteria. General criteria should consider the financial capacity of subnational governments, while special criteria emphasize the specific characteristics of subnational areas. Technical criteria are more specific, with the implementation of guidelines established by line ministries (Minister of Finance of the Republic of Indonesia, 2012).

\section{MeThoD}

\section{A. Model Specification}

This study uses a linear regression model to estimate the effect of intergovernmental transfers on poverty in Indonesia. This approach has been widely utilized by researchers for estimating the impact of decentralization on poverty (Lewis, 2016; O'dwyer \& Ziblatt, 2006; Sudhipongpracha, 2016). A Fixed-effect linear model has a significant advantage because it controls automatically all the different characteristics of districts. Thus, the analysis can be done only for interesting variables, namely intergovernmental transfer and poverty.

By assuming that poverty is a function of decentralization, a linear model can be built as follows:
First model:

$$
\operatorname{LogPov}_{\text {it }}=\beta_{0}+\beta_{1} \operatorname{logIT}{ }_{i t}+\varepsilon_{\text {it }}
$$

Second model:

$$
\operatorname{LogPov}_{\mathrm{it}}=\beta_{0}+\beta_{1} \log \mathrm{DAK}_{\mathrm{it}}+\beta_{2} \log \mathrm{DAU} \mathrm{U}_{\mathrm{it}}+\varepsilon_{\mathrm{it}}
$$

Pov $_{\text {it }}$ is donated for poverty variables, it is a poverty condition in district $i$ at year $t$. In this study, there are tree dependent variables; the number of absolute poverty, poverty gap, and poverty rate. Absolute poverty is the total number of people in a district that live under poverty line. Poverty gap is the mean shortfall of the total population from the poverty line, expressed as a percentage of the poverty line. This measure reflects the depth of poverty as well as its incidence. The poverty rate is the percentage of poverty absolute to the total population.

The dependent variable is poverty. It is calculated by summarizing the total number of people who live under poverty line determined by the Indonesian government. To be noted that Indonesian Government (BPS) has a different approach regarding poverty line towards World Bank standard. To measure poverty, BPS uses the concept of ability to meet basic needs (basic needs approach). With this approach, poverty is seen as an economic inability to meet the basic needs of food and non-food which is measured from the expenditure side. So, the Poor is the population that has an average monthly per capita expenditure below the poverty line.

This study determines two types for independent variables. In the first model, IT $_{\text {it }}$ is

Table 1.

\begin{tabular}{|c|c|c|c|c|c|}
\hline Variable & Definition & Mean & Std. Dev. & Min & Max \\
\hline pov & Number of poverty & 70046.14 & 81871.96 & 1000 & 619000 \\
\hline povgap & Poverty gap & 2.985124 & 2.599374 & 0 & 25 \\
\hline povrate & Poverty rate & 16.21223 & 9.764502 & 1 & 55 \\
\hline Idak & Log of DAK & 24.25033 & .8521705 & 16.1181 & 27.09784 \\
\hline Idau & Log of DAU & 26.51787 & .6571664 & 19.27116 & 29.43845 \\
\hline lintransf & $\begin{array}{c}\text { Log of } \\
\text { intergovernmental } \\
\text { transfer }\end{array}$ & 4057 & 26.6274 & .6229866 & 19.42693 \\
\hline
\end{tabular}

Summary of District/City Level Data

Source: Author's Creation, 2016 
defined as the total of intergovernmental transfer (DAU and DAK, not including DBH) every year that transferred by central government. Second, the intergovernmental transfer is divided into two variables, $\mathrm{DAK}_{\mathrm{it}}$ and $\mathrm{DAU}_{\mathrm{it}}$. $\mathrm{DAK}_{\mathrm{it}}$ is defined as the total amount of Dana Alokasi Khusus that is transferred every year to districts. While DAU is the total amount of Dana Alokasi Umum allocated every year for each district. This study uses natural log for both dependent and independent variables to

Table 2.

The Average Growth of Poverty and DAU in Provinces in Indonesia During 2005-2013

\begin{tabular}{|c|c|c|c|c|c|c|c|}
\hline Rank & Province & $\begin{array}{l}\text { Avg. } \\
\text { Growth } \\
\text { of } \\
\text { Poverty }\end{array}$ & $\begin{array}{l}\text { Avg. } \\
\text { Growth } \\
\text { of DAU }\end{array}$ & Rank & Province & $\begin{array}{l}\text { Avg. } \\
\text { Growth } \\
\text { of } \\
\text { Poverty }\end{array}$ & $\begin{array}{l}\text { Avg. } \\
\text { Growth } \\
\text { of DAU }\end{array}$ \\
\hline 1 & West Papua & 17.55 & 37.19 & 18 & $\begin{array}{c}\text { South } \\
\text { Kalimantan }\end{array}$ & -2.52 & 15.44 \\
\hline 2 & Papua & 5.95 & 23.07 & 19 & Aceh & -2.75 & 20.72 \\
\hline 3 & Jakarta & 2.82 & NA & 20 & $\begin{array}{c}\text { South } \\
\text { Sumatera }\end{array}$ & -3.06 & 19.27 \\
\hline 4 & $\begin{array}{c}\text { North } \\
\text { Sulawesi }\end{array}$ & 0.46 & 18.53 & 21 & $\begin{array}{c}\text { North } \\
\text { Sumatera }\end{array}$ & -3.12 & 19.98 \\
\hline 5 & Bengkulu & -1.23 & 19.06 & 22 & $\begin{array}{l}\text { Bangka- } \\
\text { Belitung } \\
\text { Islands }\end{array}$ & -3.12 & 19.06 \\
\hline 6 & Jambi & -1.48 & 17.60 & 23 & Maluku & -3.23 & NA \\
\hline 7 & $\begin{array}{l}\text { East Nusa } \\
\text { Tenggara }\end{array}$ & -1.65 & 17.04 & 24 & $\begin{array}{l}\text { Central } \\
\text { Sulawesi }\end{array}$ & -3.27 & 19.32 \\
\hline 8 & West Java & -1.72 & 14.05 & 25 & $\begin{array}{l}\text { Southeast } \\
\text { Sulawesi }\end{array}$ & -3.54 & 19.80 \\
\hline 9 & Yogyakarta & -1.73 & 18.30 & 26 & Central Java & -3.63 & 16.14 \\
\hline 10 & Riau & -1.87 & NA & 27 & Lampung & -3.76 & 17.24 \\
\hline 11 & $\begin{array}{c}\text { East } \\
\text { Kalimantan }\end{array}$ & -1.89 & NA & 28 & $\begin{array}{l}\text { North } \\
\text { Maluku }\end{array}$ & -3.87 & 17.22 \\
\hline 12 & Gorontalo & -2.05 & 17.69 & 29 & $\begin{array}{l}\text { West Nusa } \\
\text { Tenggara }\end{array}$ & -4.00 & 17.84 \\
\hline 13 & $\begin{array}{l}\text { South } \\
\text { Sulawesi }\end{array}$ & -2.09 & 16.86 & 30 & East Java & -4.51 & NA \\
\hline 14 & Banten & -2.36 & 15.69 & 31 & $\begin{array}{c}\text { West } \\
\text { Kalimantan }\end{array}$ & -4.93 & 19,93 \\
\hline 15 & $\begin{array}{c}\text { West } \\
\text { Sumatera }\end{array}$ & -2.38 & 22.06 & 32 & $\begin{array}{c}\text { Central } \\
\text { Kalimantan }\end{array}$ & -5.01 & 20,24 \\
\hline 16 & Riau Islands & -2.44 & NA & 33 & $\begin{array}{c}\text { West } \\
\text { Sulawesi }\end{array}$ & -5.35 & NA \\
\hline 17 & Bali & -2.44 & 9.42 & 34 & $\begin{array}{c}\text { North } \\
\text { Kalimantan }\end{array}$ & NA & NA \\
\hline
\end{tabular}

Note: NA means Not Available or some data is missing

Source: Author's Construction, 2016 
Table 3.

The Effect of Intergovernmental Transfer on Poverty

\begin{tabular}{ccccccc} 
& \multicolumn{2}{c}{ No. Poverty } & \multicolumn{2}{c}{ Poverty Gap } & \multicolumn{2}{c}{ Poverty Rate } \\
Variables & OLS & FE & OLS & FE & OLS & FE \\
\cline { 2 - 5 } $\begin{array}{c}\text { Log int. } \\
\text { transfer }\end{array}$ & $-0.108^{* * *}$ & $-0.124^{* * *}$ & $-0.909^{* * *}$ & $-0.949^{* * *}$ & $-3.117^{* * *}$ & $-3.173^{* * *}$ \\
\hline Constant & $13.41^{* * *}$ & $13.92^{* * *}$ & $27.25^{* * *}$ & $28.25^{* * *}$ & $99.59^{* * *}$ & $100.7^{* * *}$ \\
\hline Observations & 4,031 & 4,031 & 4,031 & 4,031 & 4,031 & 4,031 \\
\hline R-squared & & 0.067 & & 0.100 & & 0.172 \\
\hline Number of id & 491 & 491 & 491 & 491 & 491 & 491 \\
\hline
\end{tabular}

${ }^{* * *} \mathrm{p}<0.01,{ }^{* *} \mathrm{p}<0.05,{ }^{*} \mathrm{p}<0.1$

Source: Author's Construction, 2016

reduce the variance among variables.

\section{B. Data Collection}

This study uses district-level data. There is $\mathbf{5 1 2}$ districts and city being observed. All the variables data is obtained through official World Bank's website. WB has collected data from Statistical Bureau of Indonesia (BPS) and rearranged the data into its website. Thus, although the data is from the WB's website, it is officially collected by Indonesian Government through BPS. There is no different methodology on poverty determination as WB, in this case, uses Indonesian Government's approach.

\section{RESULTS AND DISCUSSION}

\section{A. The Average of Poverty Growth and DAU in Indonesia}

The poverty alleviation program in all provinces was relatively successful with the highest growth of about 5\%. The five most successful provinces regarding poverty alleviation are West Sulawesi, Central Kalimantan, West Kalimantan, East Java, and West Nusa Tenggara (see Table 2). However, there are still four provinces that showed negative performances; West Papua, Papua, Jakarta, and North Sulawesi. By categorizing the average growth,

Table 4.

The Effect of DAK and DAU on Poverty in Indonesia

\begin{tabular}{ccccccc} 
& \multicolumn{2}{c}{ No. Poverty } & \multicolumn{2}{c}{ Poverty Gap } & \multicolumn{2}{c}{ Poverty Rate } \\
Variables & OLS & FE & OLS & FE & OLS & FE \\
\cline { 2 - 6 } Log DAK & $-0.0435^{* * *}$ & $-0.0418^{* * *}$ & $-0.170^{* * *}$ & $-0.224^{* * *}$ & $-0.713^{* * *}$ & $-0.804^{* * *}$ \\
\hline Log DAU & $-0.0522^{* * *}$ & $-0.0687^{* * *}$ & $-0.633^{* * *}$ & $-0.623^{* * *}$ & $-2.047^{* * *}$ & $-2.021^{* * *}$ \\
\hline Constant & $12.98^{* * *}$ & $13.43^{* * *}$ & $23.95^{* * *}$ & $24.93^{* * *}$ & $88.17^{* * *}$ & $89.36^{* * *}$ \\
\hline Observations & 3,936 & 3,936 & 3,936 & 3,936 & 3,936 & 3,936 \\
\hline R-squared & & 0.065 & & 0.091 & 0.158 \\
\hline Number of id & 491 & 491 & 491 & 491 & 491 & 491 \\
\hline
\end{tabular}

Standard errors in parentheses, ${ }^{* * *} \mathrm{p}<0.01,{ }^{* *} \mathrm{p}<0.05,{ }^{*} \mathrm{p}<0.1$

Source: Author's Construction, 2016 
there are five categories of poverty performances. Nine provinces showed average growth by $1 \%$, eight provinces of about $2 \%$ and seven provinces showed $3 \%$, and three of about $4 \%$.

Table 4 shows that the increase of DAU was not surely followed by poverty reduction. West Papua had the highest average growth of DAU but also had the worst performance in poverty reduction. North Sulawesi almost had fluctuation regarding poverty as its poverty growth is almost zero $(0.46 \%)$. Moreover, the positive effect of IT can be observed in some provinces in Indonesia. Central Kalimantan had an average increase of DAU about $20.24 \%$ and showed satisfying performance related to its poverty that decreased by $5.01 \%$. West Kalimantan had similar/close performance that had poverty reduction about 4.93 with average growth by 19.93. In short, most provinces in Indonesia showed a positive effect on poverty after increasing IT allocation despite the different rates.

\section{B. The Estimation Result}

Table 3 shows all the results for the model I that test the effect of intergovernmental transfer on three poverty indicators. For each independent variable, the test includes a fixed-effect test to give a different result of the coefficient. The result shows that intergovernmental transfer is related to all indicators of poverty; poverty absolute, poverty gap, and poverty rate. After considering fixed-effect, all coefficients are corrected and tends to become smaller. Increasing governmental transfer by $1 \%$ will decrease the number of poor by $0.124 \%$ or, in other words, increasing IT for the district by $10 \%$ will reduce absolute poverty by $1.24 \%$. Regarding poverty gap, increasing governmental transfer by $1 \%$ will decrease the poverty gap by $0.949 \%$, or in other words, increasing IT for the district by $10 \%$ will reduce poverty gap by $9.49 \%$. Moreover, the poverty rate also has a significant association with the intergovernmental transfer. Increasing governmental transfer by $1 \%$ will decrease the poverty rate by $3.17 \%$ (see Table 3 ).

The results for model 2 can be observed in Table 4. The intergovernmental transfer is divided into two variables, DAK and DAU, in order to test the different effect of intergovernmental type on poverty. In general, both DAK and DAU have a significant correlation on all poverty indicators. In the fourth test, this study runs the same test by dividing intergovernmental transfer into two, they are DAK and DAU. An increase of DAK and DAU by $1 \%$ will reduce the poverty number by $0.043 \%$ and $0.052 \%$, respectively. Their effects are corrected after considering the district fixed-effect, they are $0.0418 \%$ and $0.068 \%$.

The DAU and DAK also significantly relate to poverty gap in districts in Indonesia. A 1\% increase of DAU will reduce the poverty gap by $0.62 \%$, or $10 \%$ increase of DAU will reduce the poverty gap by $6.23 \%$. Thus, the DAU has a higher effect on DAK regarding poverty gap reduction. This condition is similar to the different effect on poverty rate where DAU has a significant and higher effect than DAK. A $1 \%$ increase of DAU can reduce the poverty rate by $2.02 \%$ whereas DAK is only $0.80 \%$. In short, DAU looks like a more effective instrument than DAK in order to reduce three poverty indicators for districts level in Indonesia.

\section{Discussion}

Decentralization has positive effects on poverty only if the assumptions of the theory of fiscal decentralization are satisfied. One of the main conditions is the ability of local governments to manage the transfer of funds for economic development. In addition, local governments must be able to demonstrate the ability to accommodate the demands of their people. An efficiency in providing public goods and services is related strongly to the ability of local government to understand the demand of its society. This study proves that intergovernmental transfer has a significant effect on poverty reduction. All poverty indicators show strong associations to intergovernmental transfers. By increasing 1\% of IT allocation, the poverty absolute in each district will be reduced by $0.12 \%$, or a $10 \%$ increase of intergovernmental allocation will reduce poverty by $1.24 \%$. Moreover, the intergovernmental transfer also directly affects poverty gap and poverty rate. Increasing 10\% of transfers to local government will reduce the poverty gap and poverty rate by $9.49 \%$ and $31.73 \%$, respectively.

The effectiveness of DAK and DAU on poverty reduction is different. DAU seems as more effective policy than DAK. An increase of DAK and DAU by $1 \%$ will reduce the poverty number by $0.0418 \%$ and $0.068 \%$, respectively. It means that DAU gives more effect on poverty reduction than DAK. These findings are supported by another study (Lewis, 2016) that finds the type of intergovernmental transfer brings different effect on poverty.

The difference between DAK and DAU is not significantly huge, it is only $0.027 \%$. It may indicate that DAU is not much more effective than DAK regarding the flexibility of the policy. Increasing 1\% of DAU is not as simple as increasing the DAK as the amount of DAU is much higher than DAK. Thus, DAU, in an ideal condition of decentralization, must have a much higher effect of poverty than DAK. It may indicate that the utilization of DAU by local governments is not targeted effectively to poverty reduction. DAU may be allocated only for routine spending of local government such as apparatus and administrative activities. 
In contrast, the intervention of central government through DAK has a significant effect on poverty reduction. This result is supported by (Lewis, 2016) who concludes that the intergovernmental transfer that co-administered by the provincial government and districts government has a higher and significant effect that only managed by provincial government regarding the provision of public goods. He further states that the positive impact of the co-administered fund may be the results of development on the construction and maintenance of local facilities that directly related to services delivery.

The intervention of the central government through DAK showed a more effective policy than what local government did. In decentralization theorem, there is one condition that must be fulfilled to trigger the positive result of decentralization, that is the low cost of mobilization of society. The local should be able to move to a district that has benefit to a certain people. By doing so, the cost of the economy will be minimized and the effectiveness will be increased. In other words, people will choose to settle in a district that gives more benefit to them, such as public goods. In the case of Indonesia, as the cost of mobilization is still high, the efficiency of decentralization is not yet fulfilled or satisfied. Thus, the benefit of decentralization has not shown its best performance yet in Indonesia.

The different effect of DAK and DAU on poverty in which DAK has a relatively higher effect indicates that the decentralization has not been conducted properly. DAU, as unconditional grants, is unable to significantly alleviate poverty in Indonesia. It may be related to the disability of local government to utilize the funds. It may also relate to the political will of the local government, including legislative, to allocate the funds on more pro-poor policies.

Regarding inefficiency spending of unconditional grants in Indonesia, Schulze and Sjahrir (Fahmi, 2015) state that although decentralization has increased service delivery and more demanded products, it was spent inefficiently by local government, both regional and provincial levels. Firman (2009) state that inefficiency in grant spending is caused by many local governments that acted like a "king" in their territory. Even though some regions have excellent leaders (Bupati and Walikota), many are under leaders who have no brilliant idea regarding efficient and effective government spending.

Sumarto et al. in Fahmi (2015) conclude that decentralization in Indonesia faces a lack of local institutional capacity in increasing local development, delivering public goods, and reducing poverty. Increasing fiscal decentralization does not seem as a simple solution as many problems may arise. Further, Lewis in Fahmi (2015) notes that low public participation in planning and monitoring of local spending has reduced the effectiveness of governmental spending.

World Bank (2016) has proposed three strategies for increasing the effectiveness in the utilization of DAU in Indonesia. First, the monitoring of local government performance must be increased, especially in allocating process. The main challenge in Indonesia regarding fiscal decentralization is that the political will on allocating the pro-poor policies is relatively low. This may be worse as some local governments do not understand the mechanism on poverty alleviation program, so they tend to disagree on poverty-related spending. Second, the independence of fiscal of local government must be increased. If the intergovernmental transfer tends to spend fully on civil servants' salaries, then its effectiveness on poverty reduction may be less significant. The last is reducing the spending for the administrative expenditure of local government. The local government should prioritize their spending in areas that will have a direct impact on the provision of public services, economic growth, and poverty alleviation activities.

\section{Conclusion}

\section{A. Conclusion}

The decentralization reduces poverty by promoting efficiency and increasing the ability of local government to manage its own spending. More transfers mean that more power for local government to execute its policies. However, decentralization may lead to ineffectiveness as the ability and the political will may be different from local government. In some cases, centralized funding looks more effective to reduce poverty.

This study proves that intergovernmental transfer (IT) has a positive effect on poverty in Indonesia. By increasing 1\% of IT allocation, the poverty absolute in each district will be reduced by $0.12 \%$, or $10 \%$ increase of IT will reduce poverty by $1.24 \%$. Moreover, the intergovernmental transfer also directly affects poverty gap and poverty rate. Increasing $10 \%$ of transfers to local government will reduce the poverty gap and poverty rate by $9.49 \%$ and $31.73 \%$, respectively. However, by separating IT into DAK and DAU, the different effect of IT is revealed. DAU has a higher effect than DAK regarding poverty alleviation. An increase of DAU by $1 \%$ will reduce the poverty number by $0.068 \%$. In contrast, DAK only has $0.0418 \%$ reduction.

However, as the difference is not really significant, the effectiveness of DAU is doubted. DAU must be much higher than DAK as DAU allocation every year is much higher than DAK. Further, based on decentralization theory, DAU must have a higher 
effect on poverty than DAK as DAU is unconditional grant while DAK is a conditional grant. As the difference is only $0.027 \%$, DAU may indicate ineffectiveness. It may indicate that the utilization of DAU by local governments is not targeted effectively to poverty reduction. In contrast, the intervention of central government through DAK has a significant effect on poverty reduction.

\section{B. Limitation}

The utilization of the linear regression to estimate the effect of intergovernmental transfers on poverty is not free from bias. Although this study uses panel data to control other invariant-time variables, still there are many time-variant variables that may not be controlled. It may lead to coefficients bias, the coefficient may under or over estimated. Therefore, further researches are required to fix these problems and obtain more robust coefficient.

\section{ACKNOWLEDGEMENT}

This paper is a result of a long discussion with researchers in National Institute of Public Administration of Republic of Indonesia (LAN-RI). I express my gratitude to all researchers in LAN. Special thanks for World Bank for the amazing website in which all the data is extracted.

\section{REFERENCES}

Alam Siddiquee, N. (2006). Public management reform in Malaysia: Recent initiatives and experiences. International Journal of Public Sector Management, 19(4), 339-358. http:// doi.org/10.1108/09513550610669185

Ali Khan, S. (2013). Decentralization and Poverty Reduction: A Theoretical Framework for Exploring the Linkages. International Review of Public Administration, 18(2), 173-210. http://doi.org/10.1080/12294659.2013.1080 5256

Beard, V. A. (2007). Household Contributions to Community Development in Indonesia. World Development, 35(4), 607-625. http://doi. org/10.1016/j.worlddev.2006.06.006

Biltonen, E., \& Dalton, J. A. (2003). A WaterPoverty Accounting Framework: Analyzing the Water-Poverty Link. Water International, 28(4), 467-477. http://doi. org/10.1080/02508060308691724

Bjornestad, L. (2009). Fiscal Decentralization, Fiscal Incentives, and Pro-poor Outcomes: Evidence from Vietnam (Economics Working Papers No. 168). ADB Economics Working Paper Series. Retrieved from http://hdl.handle. net/11540/1817

Cavalieri, M., \& Ferrante, L. (2016). Does Fiscal Decentralization Improve Health Outcomes?
Evidence from Infant Mortality in Italy. Social Science \& Medicine, 164, 74-88. http://doi. org/10.1016/j.socscimed.2016.07.017

Fahmi, F. Z. (2015). Regional Dynamics in a Decentralized Indonesia. Bulletin of Indonesian Economic Studies, 51(3), 484-486. http://doi. org/10.1080/00074918.2015.1111798

Firman, T. (2009). Decentralization Reform and Local Government Proliferation in Indonesia: Towards a Fragmentation of Regional Development. Review of Urban \& Regional Development Studies, 21(2-3), 143-157. http://doi.org/10.1111/j.1467940X.2010.00165.X

Greenstein, J., Gentilini, U., \& Sumner, A. (2014). National or International Poverty Lines or Both? Setting Goals for Income Poverty after 2015. Journal of Human Development and Capabilities: A Multi-Disciplinary Journal for People-Centered Development., 15(2-3), 132146. http://doi.org/10.1080/19452829.2014. 899565

Hammer, J., \& Spears, D. (2016). Village Sanitation and Child Health: Effects and External Validity in a Randomized Field Experiment in Rural India. Journal of Health Economics, 48, 135-148. http://doi.org/10.1016/j. jhealeco.2016.03.003

Hankla, C. R. (2009). When is Fiscal Decentralization Good for Governance? Publius, 39(4), 632-650. http://doi.org/10.1093/publius/pjn034

Hull, T. H. (2001). Counting for Democracy: Development of National Statistical Systems in a Decentralised Indonesia. Bulletin of Indonesian Economic Studies, 37(2), 253-258. http://doi. org/10.1080/00074910152390919

Irawan, A. (2015). Regional Income Disparities in Indonesia: Measurements, Convergence Process, and Decentralisation. Bulletin of Indonesian Economic Studies, 51(1), 148-149. http://doi.org/10.1080/00074918.2015.102 3415

Khan, S. A. (2016). International Review of Public Administration Decentralization and Poverty Reduction: A Theoretical Framework for Exploring the Linkages EXPLORING THE LINKAGES, 4659(November). http://doi.org/1 $0.1080 / 12294659.2013 .10805256$

Law of the Republic of Indonesia Number 33 of 2004 on Financial Balance between Central and Local Government, Pub. L. No. 33 (2004). Indonesia: 2004.

Lewis, B. D. (2016). Is Central Government Intervention Bad for Local Outcomes? Mixed Messages from Indonesia. The Journal of Development Studies, 52(2), 300-313. http:// doi.org/10.1080/00220388.2015.1068293

Loayza, N. V., Rigolini, J., \& Calvo-González, O. (2014). 
More Than You Can Handle: Decentralization and Spending Ability of Peruvian Municipalities. Economics and Politics, 26(1), 56-78. http:// doi.org/10.1111/ecpo.12026

Malik, S., Mahmood-Ul-Hassan, \& Hussain, S. (2006). Fiscal decentralisation and economic growth in Pakistan. Pakistan Development Review, 45(4). http://doi.org/10.1080/13547860.201 1.539397

Mansoob Murshed, S., Zulfan Tadjoeddin, M., \& Chowdhury, A. (2009). Is Fiscal Decentralization Conflict Abating? Routine Violence and District Level Government in Java, Indonesia. Oxford Development Studies, 37(4), 397-421. http:// doi.org/10.1080/13600810903305224

Minister of Finance of the Republic of Indonesia. Regulation of the Minister of Finance of the Republic of Indonesia Number 06/ PMK.07/2012 on Implementation and Accountability Budget Transfers to Regions, Pub. L. No. 06/PMK.07 (2012). Indonesia.

Miranti, R., Duncan, A., \& Cassells, R. (2014). Revisiting the Impact of Consumption Growth and Inequality on Poverty in Indonesia during Decentralisation. Bulletin of Indonesian Economic Studies, 50(3), 461-482. http://doi. org/10.1080/00074918.2014.980377

O'dwyer, C., \& Ziblatt, D. (2006). Does Decentralisation Make Government More Efficient and Effective? Commonwealth \& Comparative Politics, 44(3), 326-343. http:// doi.org/10.1080/14662040600997064

Okurut, K., \& Charles, K. J. (2014). Household demand for sanitation improvements in low-income informal settlements: A case of East African cities. Habitat International, 44, 332-338. http://doi.org/10.1016/j. habitatint.2014.07.014

Pal, S., \& Wahhaj, Z. (2015). Fiscal Decentralisation, Local Institutions and Public Good Provision: Evidence from Indonesia. Journal of Comparative Economics, 0, 1-27. http://doi. org/10.1016/j.jce.2016.07.004

Qibthiyyah, R., \& Utomo, A. J. (2016). Family Matters: Demographic Change and Social Spending in Indonesia. Bulletin of Indonesian Economic Studies, 52(2), 133-159. http://doi.org/10.10 80/00074918.2016.1211077

Schalembier, B. (2016). The Impact of Exposure to Other Countries on Life Satisfaction: An International Application of the Relative
Income Hypothesis. Social Indicators Research, 128(1), 221-239. http://doi.org/10.1007/ s11205-015-1027-1

Shah, A. (2007). Local Public Financial Management. World Bank.

Steiner, S. (2007). Decentralisation and Poverty: Conceptual Framework and Application to Uganda. Public Administration and Development, 27(2), 175-185. http://doi. org/10.1002/pad.445

Sudhipongpracha, T. (2016). Do the Poor Count in Fiscal Decentralization Policy? A Comparative Analysis of the General Grant Allocation Systems in Indonesia and Thailand Comparative Analysis of the General Grant Allocation Systems. Journal of Asian Public Policy, 0(0), 1-18. http://doi.org/10.1080/17 516234.2016.1195946

Sudhipongpracha, T., \& Wongpredee, A. (2016). Fiscal Decentralization in Comparative Perspective : Analysis of the Intergovernmental Grant Systems in Indonesia and Thailand Fiscal Decentralization in Comparative Perspective : Analysis of the Intergovernmental Grant Systems in Indonesia and Thailand. Journal of Comparative Policy Analysis: Research and Practice, 0(0), 1-17. http://doi.org/10.1080/1 3876988.2016.1138659

Todaro, M. P., \& Smith, S. C. (2009). Economic Development. Addison-Wesley.

Uchimura, H. (2012). Fiscal Decentralization and Development: Experiences of Three Developing Countries in Southeast Asia. Palgrave Macmillan UK.

Van, V. B., \& Sudhipongpracha, T. (2015). Exploring Government Budget Deficit and Economic Growth: Evidence from Vietnam's Economic Miracle. Asian Affairs: An American Review, 42(3), 127-148. http://doi.org/10.1080/0092 7678.2015.1048629

WorldBank.(2005).IntroductiontoPovertyAnalyses. Poverty Manual, All, JH Revision. Retrieved from http://siteresources.worldbank.org/ PGLP/Resources/PovertyManual.pdf

Yeoh, E. K.-K., Ling, S. Y.-P., \& Shy, F. P. (2012). Fiscal reform, decentralization and poverty alleviation in the context of China's 12th FiveYear Plan. Journal of Asian Public Policy, 5(2), 231-251. http://doi.org/10.1080/17516234. 2012.678737 